\title{
Leadership Style, Organization Culture, Motivation, and Principal Supervision of Teachers:
}

\author{
Their Effects on Teacher Performance
}

\author{
Haryono Wasito*, Pieter Sahertian, Vinus Maulina \\ Universitas PGRI Kanjuruhan Malang \\ Malang, Indonesia \\ *haryonowarsito@gmail.com, pieter_porto@hotmail.com,vinus@unikama.ac.id
}

\begin{abstract}
This study aimed to analyze the effect of leadership style, organizational culture, motivation and principal supervision of teachers on teacher performance at elementary schools in Malang Regency, Indonesia. The results of this study showed that, simultaneously, leadership style, organizational culture, motivation, and principal supervision of teachers had a significant effect on teacher performance. Partially there was no significant influence of leadership style and motivation of school principals on teacher performance, while organizational culture and principal supervision had a significant effect on teacher performance.
\end{abstract}

Keywords-leadership style, organizational culture, motivation, principal supervision of teachers, teacher performance

\section{INTRODUCTION}

The success of education is strongly associated with the role of the teacher, because the teacher is the most determining component of the success of students in the teaching and learning process [1]. Therefore, without the support of professional and qualified teachers, any efforts done to improve the quality of education will have no significant impact on the learning process. Professional teachers refer to teachers who carry out their work in accordance with the demands of the profession. Teacher performance plays a major role in supporting the creation of an educational process and improving the quality of student academic achievement [2].

Research shows that leadership style is one of the factors that can affect teacher performance at school [3,4], although several other studies have shown that there is no influence of leadership style on employee performance [5]. The results of another study indicate that teacher performance is also influenced by organizational culture. Moreover, Fitria [6] found that organizational culture had a positive impact on teacher performance. Organizational culture in a good work environment can increase comfort in work and ultimately can improve employee performance [7,8].

Motivation is also an important factor that determines organizational goals in enhancing teacher performance [9]. Motivation will encourage teachers to complete their tasks effectively [10]. Given the importance of motivation for teachers, it is expected that the principal as a leader will be able to motivate teachers to work in accordance with the vision and mission of the school. However, without continuous supervision, the motivation given by the principal to teachers tends to be less effective in improving teacher performance [11]. Leniwati and Arafat [12] have found a positive effect of principal supervision on teacher performance. With the supervision of the principal, the teacher will better recognize mistakes that occur in the learning process and during the completion of student assignments at school [13]. On the other hand, Murtiningsih et al. [14] argue that principal supervision alone, without being supported by good personal communication skills, has no significant effect on teacher performance.

Based on the previous studies explained above, it is clear that there are different results regarding factors that affect teacher performance and thus, further studies need to be conducted on the effect of leadership style, organizational culture, motivation and supervision of school principal on the performance of teachers at elementary schools in Malang Regency, Indonesia.

\section{A. Leadership Style and Teacher Performance}

According to Saputra [3], principal's leadership style that meets the needs of teachers can create a work atmosphere that is able to trigger morale for teachers and affect teacher performance. Teachers will be motivated to work properly when the work atmosphere provides a sense of security and respect; the teachers will feel excited to complete their tasks and perform better at work [4]. However, Saleem et al. [5] found that there was no significant effect of the principal's leadership style on teacher performance.

H1: Leadership style has a significant effect on teacher performance.

\section{B. Organizational Culture and Teacher Performance}

Organizational culture will empower everyone in the organization to achieve organizational goals. A good 
organizational culture improves teacher performance. The principal who is competent in leadership will pay attention to the organizational culture that exists in the school in order to provide a sense of security and comfort to all school members in serving the students. A safe school atmosphere indicates that the organizational culture is good, so it can improve teacher performance. In short, it can be said that organizational culture has an effect on teacher performance [15].

$\mathrm{H} 2$ : Organizational culture has a significant effect on teacher performance.

\section{Motivation and Teacher Performance}

Motivation is a driving force that moves, directs, and determines the behaviour of a person in an organization to be disciplined and motivated to perform well [16]. Apart from determining disciplinary behaviour, motivation can also increase enthusiasm in the workplace. However, Nuraisyah [11] suggests a different finding, that is motivation without the supervision of the principal has no significant effect on teacher performance.

H3: Motivation has a significant effect on teacher performance.

\section{Principal Supervision of Teachers and Teacher Performance}

Organizations with leaders who are competent in terms of leadership and who are able to create a good organizational culture including providing motivation to the subordinates can probably fail to run in accordance with the vision and mission of the school because there is no supervision from the leader (principal) towards the subordinates [17]. According to Murtiningsih et al. [14], the principal's interpersonal communication skills may be less effective due to the absence of regular supervision. Supervision provided by the school's principal as the policy maker in determining the vision, mission, and goals of the school in the future is strongly needed. If in issuing policies or regulations in schools the principals fail to carry out supervision, it can be predicted that teacher performance will cease to work well and even deviate from the goals of the organization [12].

H4: Principal supervision of teachers has a significant effect on teacher performance.

\section{METHODS}

\section{A. Research Methods}

This study was designed as a correlational study that aimed to investigate the causal relationship between variables. Purposive sampling technique was applied to select 196 certified teachers from the National Basic Education Data. The teachers were currently teaching in the elementary schools in Malang Regency, Indonesia. The data were collected using Likert Scale-based closed-ended questionnaires.
Data analysis was performed using multiple linear regression analysis to examine the simultaneous and partial effects of the dependent variables on the independent variable. The statistical analysis was assisted by SPSS V.20 program.

\section{B. Research Findings}

1) Multiple linear regression analysis: The statistical test in the multiple linear regression analysis was conducted to find the value of $F$ (for simultaneous effect) and the value of $t$ (Tables 1 and 2).

TABLE I. ThE F-Test RESUlt

\begin{tabular}{|c|l|l|l|l|l|c|}
\hline \multirow{4}{*}{1} & \multicolumn{1}{|c|}{ Model } & $\begin{array}{c}\text { Sum of } \\
\text { Squares }\end{array}$ & \multicolumn{1}{|c|}{ df } & $\begin{array}{c}\text { Mean } \\
\text { Square }\end{array}$ & F & Sig. \\
\cline { 2 - 7 } & Regression & 813,681 & 4 & 203,420 & 38,771 &, $000^{\mathrm{b}}$ \\
& $\begin{array}{l}\text { Residual } \\
\text { Total }\end{array}$ & 1002,135 & 191 & 5,247 & & \\
\hline
\end{tabular}

TABLE II. MultiPle LINEAR REGRESSION TEST Results

\begin{tabular}{|c|c|c|c|c|c|c|}
\hline \multicolumn{7}{|c|}{ Coefficients $^{\mathrm{a}}$} \\
\hline & \multirow{2}{*}{ Model } & \multicolumn{2}{|c|}{$\begin{array}{l}\text { Unstandardized } \\
\text { Coefficients }\end{array}$} & \multirow{2}{*}{$\begin{array}{c}\begin{array}{c}\text { Standardized } \\
\text { Coefficients }\end{array} \\
\text { Beta }\end{array}$} & \multirow{2}{*}{$\mathbf{t}$} & \multirow{2}{*}{ Sig } \\
\hline & & $\boldsymbol{B}$ & $\begin{array}{c}\text { Std. } \\
\text { Error }\end{array}$ & & & \\
\hline \multirow{5}{*}{1} & (Constant) & 20,383 & 2,138 & & 9,535 &, 000 \\
\hline & $\begin{array}{l}\text { Leadership } \\
\text { Style }\end{array}$ &, 045 &, 065 & ,072 & ,688 & ,492 \\
\hline & $\begin{array}{l}\text { Organizational } \\
\text { Culture }\end{array}$ &, 134 & ,046 & ,261 & 2,917 & ,004 \\
\hline & Motivation &,- 049 & ,059 &,- 077 &,- 832 & ,407 \\
\hline & $\begin{array}{l}\text { Principal } \\
\text { Supervision }\end{array}$ & ,266 & ,033 & ,502 & 7,955 & , 000 \\
\hline
\end{tabular}

a. Dependent Variable: performance.

Source: SPSS output, Primary data is processed

The result of the multiple linear regression analysis showed that leadership style and principal supervision of teachers simultaneously had a positive (38.771) and significant effect on teacher performance (sig. $0.000<0.05$ ). It thus indicated that Hypothesis 1 was accepted. The t-test value of leadership style was 0.688 , and the significance level $(0.492)$ was greater than 0.05. It was therefore concluded that leadership style had no effect on teacher performance; hence, Hypothesis 2 was rejected. Furthermore, the t-test value for organization culture was 2.917 and the significance level (0.004) was smaller than 0.05 . Therefore, it can be said that organizational culture had an effect on teacher performance; hence, Hypothesis 3 was accepted. Meanwhile, motivation achieved a t-test value of 0.832 and a significance level $(0.407)$ that is bigger than 0.05 ; hence, Hypothesis 4 was rejected. On the other hand, Hypothesis 5 was accepted because the t-test value of principal supervision was 7.955 and the significance value $(0.000)$ was smaller than 0,05 . Therefore, it was concluded that principal supervision of teachers had an effect on teacher performance. 
TABLE III. THE T-TEST RESULT

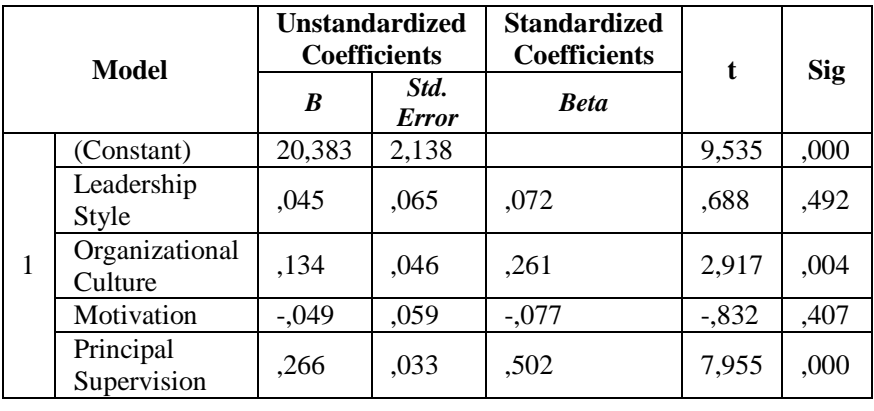

The Result of the Multiple Linear Regression Analysis.

Based on table 3, the result of the multiple linear regression analysis showed that leadership style, organizational culture, motivation and principal supervision of teachers simultaneously had an effect on teacher performance. While leadership style and motivation partially had no effect on teacher performance, organization culture and principal supervision of teachers partially had a significant effect on teacher performance.

\section{RESULTS AND DISCUSSION}

A. Leadership Style, Organizational Culture, Motivation and Principal Supervision of Teachers Simultaneously Had an Effect on Teacher Performance

The results of the hypothesis testing showed that leadership style, organizational culture, motivation and principal supervision of teachers simultaneously had a significant effect on teacher performance. This finding revealing that teacher performance was influenced by some factors, including leadership style, school culture and motivation. Therefore, better leadership style, organizational culture, motivation and principal supervision of teachers will lead to the improvement of teacher performance. This finding is similar to the previous studies mentioning that teacher performance is affected by several factors, including leadership style, organizational culture, motivation and principal supervision of teachers $[18,19]$. In contrast, Saputra [3] found that leadership style had no effect on teacher performance, but there was a significant effect of the work environment or organizational culture on teacher performance.

\section{B. The Effect of Leadership Style on Teacher Performance}

Based on the result of the hypothesis testing, it can be stated that leadership style partially had no effect on teacher performance. This finding thus confirms what was conveyed by Saputra [3] that there was no influence of leadership style on teacher performance, but the work atmosphere/organizational culture had a significant effect on teacher performance. Based on the survey results, it was concluded that leadership style alone could not affect teacher performance without the support of a good organizational culture, directed motivation from the principal and continuous principal supervision of the teachers. The results of this study, however, are not in line with those expressed by Wachira et al. [4], that leadership style and organizational culture had a significant effect on teacher performance.

\section{The Effect of Organizational Culture on Teacher Performance}

The result of the hypothesis testing showed that organizational culture partially had a significant effect on teacher performance. Therefore, this finding corroborates the results of the research by Handayani and Rasyid [17], which showed that with simple regression and multiple regression data analyses, there was a significant effect of organizational culture on teacher performance. This finding also strengthens the findings of a previous study which showed that the trust given to teachers and organizational culture of a school had a significant effect on teacher performance [6]. However, on the other hand, a study has proven that organizational culture was an ineffective driver for expressing employee productivity or performance at the Khyber-Pakhtunkhwa Bank in Pakistan [7].

\section{The Effect of Motivation on Teacher Performance}

According to the result of the hypothesis testing, motivation partially had no effect on teacher performance. This finding confirms those suggested by Putra et al. [20], stating that motivation had no significant effect on employee performance. However, performance can significantly increase due to the influence of leadership style, organizational culture and job satisfaction. This shows that motivation alone cannot improve teacher performance without being supported by organizational culture and job satisfaction from each teacher. The results of this study contradict the findings of Werang et al. [9] which showed that motivation and morale had a positive and significant effect on teacher performance. The motivation was one of the factors that had a significant effect on teacher performance besides leadership style and school culture.

\section{E. The Effect of Principal Supervision of Teachers on Teacher Performance}

The result of the hypothesis testing showed that principal supervision of teachers had a significant effect on the performance of elementary school teachers in Malang Regency, Indonesia. This finding corroborates those suggested by Murtiningsih et al. [14] that principal supervision of teachers and principal's interpersonal communication (motivation) had a significant effect on teacher performance. In addition, previous research has also proven that the motivation and supervision of school principals had a very significant effect on teacher performance [14,18].

\section{CONCLUSION}

The performance of elementary school teachers in Malang Regency, Indonesia was determined by the increasing quality of the schools' organizational culture. A good organizational culture allows teachers to feel more comfortable in carrying out their tasks at school every day and be encouraged to improve their quality and innovate in presenting the lessons. These 
qualities will have a positive impact on creating a more attractive learning atmosphere for the students. Principals as supervisors should carry out their function as a regulator of discipline, administrative order, and the implementation of procedures for every school member, especially teachers. Through these functions, principal supervision of teachers will help improve teacher performance. However, this study showed that leadership style and motivation from principals had no significant effect on teacher performance. This could happen because the school already had a good organizational culture so that the teachers were indirectly motivated to improve their performance. The principal supervision of teachers that runs well shows that the principal has successfully carried out his function as an organization leader. In other words, principal supervision of teachers reflects the principal's leadership style.

The limitations of this study can be associated with the measurement of the teacher performance. In this study, teacher performance was measured using self-assessment or an evaluation conducted based on personal perceptions. Therefore, to get more valid results, future research should consider using the certified teacher performance report as the instrument to assess teacher performance. In addition, researchers can also investigate the effect of other factors on teacher performance, considering the limited number of variables that could be covered by this study.

\section{ACKNOWLEDGMENT}

This article publication in ANCOSH 2020 proceeding is supported by the research grant funded by The Directorate of Higher Education Ministry of Research and Technology Republic of Indonesia with the decree number: 039/SP2H/LT/MONO/L7/2019.

\section{REFERENCES}

[1] S. Wanto, "Kompetensi Guru (Suatu Konsep Teoritis dan Aplikasinya Dalam Proses Belajat Mengajar)," Murabbi, vol. 1, no. (2), 2018.

[2] A. Purwanto, M. Asbari, R. Pramono, P. Senjaya, A.H. Hadi, dan Y. Andriyani, "Pengaruh Kepemimpinan terhadap Kinerja Guru Sekolah Dasar dengan Keterlibatan Kerja dan Budaya Organisasi sebaga Mediator," EduPsyCouns: Journal of Education, Psychology and Counseling, vol. 2, no. (1), pp. 50-63, 2020.

[3] Saputra, "Pengaruh Gaya Kepemimpinan Kepala Sekolah Dan Suasana Kerja Terhadap Kinerja Guru,” Manajer Pendidikan, vol. 13, no. (3), pp. 249-259, 2019.

[4] F.M. Wachira, M. Gitumu, and Z. Mbugua, "Effect of Principals" Leadership Styles on Teachers' Job Performance in Public Secondary Schools in Kieni West Sub- County," Lnternational Journal of Humanities and Social Science Invention, vol. 6, no. (8), pp. 72-86, 2017.
[5] A. Saleem, S. Aslam, H.B. Yin, and C. Rao, "Principal leadership styles and teacher job performance: Viewpoint of middle management," Sustainability (Switzerland), vol. 12, no. (8), pp. 1-15, 2020.

[6] H. Fitria, "The influence of organizational culture and trust through the teacher performance in the private secondary school in Palembang," International Journal of Scientific and Technology Research, vol. 7, no. (7), pp. 82-86, 2018.

[7] S. Rehman, H.U. Rahman, M. Zahid, and M. Asif, "Leadership Styles, Organizational Culture and Employees' Productivity: Fresh Evidence from Private Banks of Khyber-Pakhtunkhwa, Pakistan,” Abasyn Journal of Social Sciences, AICTBM-18, pp. 1-15, 2018.

[8] K.S. Alhosani and K.B. Bin. Yaakub, "The Effect Organizational Culture and Total Quality Management Practices in Secondary School Performance of Abu Dhabi," European Journal of Multidisciplinary Studies, vol. 5, no. (1), pp. 58-60, 2020

[9] B.R. Werang, O. Irianto, and H.P. Asmaningrum, "Pengaruh Motivas dan Semangat Kerja terhadap Kinerja Guru SD di Distrik Mindiptana, Papua," Musamus Journal of Primary Education, vol. 1, no. (2), pp. 093-103, 2019

[10] P. Gabiella dan H. Tannady, "Pengaruh Motivasi Dan Disiplin Kerja Terhadap Kinerja Pegawai,” Jurnal STIE Semarang, vol. 11, no. (2), pp. 48-59, 2019.

[11] S. Nuraisyah, "Pengaruh Kepemimpinan Kepala Sekolah, Budaya Organisasi dan Motivasi Kerja Guru Terhadap Kinerja Guru Pada SMP Negeri di Kecamatan Pandaan Kabupaten Tapanuli Tengah Sumatra Utara," Jurnal Bisnis dan Manajemen Eksekutif, vol. 1, no. (1), 2012

[12] L. Leniwati dan Y. Arafat, "Implementasi Supervisi Akademik Kepala Sekolah Untuk Meningkatkan Kinerja Guru," JMKSP (Jurnal Manajemen, Kepemimpinan, Dan Supervisi Pendidikan), vol. 2, no. (1), pp. 106-114, 2017.

[13] Magistar dan S. Kuala, "Hubungan Motivasi Kerja Dan Supervis Kepala Sekolah Dengan Kinerja Guru Smp Negeri Di Kecamatan Babahrot Aceh Barat Daya," Jurnal Administrasi Pendidikan: Program Pascasarjana Unsyiah, vol. 7, no. (1), pp. 7-12, 2017.

[14] M. Murtiningsih, M. Kristiawan, and B. Lian, "The Correlation Between Supervision of Headmaster and Interpersonal Communication with Work Ethos of the Teacher," European Journal of Education, vol. 6, no. (1), pp. 246-256, 2019.

[15] A.T.Y. Wulandari, "Pengaruh Budaya Organisasi Terhadap Kinerja Guru Di Smk Negeri 2 Ngawi Tahun 2014," EQUILIBRIUM: Jurnal Ilmiah Ekonomi Dan Pembelajarannya, vol. 4, no. (2), p. 144, 2016.

[16] P. Gabiella dan H. Tannady, "Pengaruh Motivasi Dan Disiplin Kerja Terhadap Kinerja Pegawai," Jurnal STIE Semarang, vol. 11, no. (2), pp. 48-59, 2019.

[17] T. Handayani dan A.A. Rasyid, "Pengaruh Kepemimpinan Kepala Sekolah, Motivasi Guru, Dan Budaya Organisasi Terhadap Kinerja Guru Sma Negeri Wonosobo," Jurnal Akuntabilitas Manajemen Pendidikan, vol. 3, no. (2), pp. 264-277, 2015.

[18] A. Jihad, A. Murniati, dan Yusrizal, "Hubungan Motivasi Kerja Dan Supervisi Kepala Sekolah Dengan Kinerja Guru Smp Negeri Di Kecamatan Babahrot Aceh Barat Daya," Jurnal Administrasi Pendidikan: Program Pascasarjana Unsyiah, vol. 7, no. (1), pp. 7-12, 2017

[19] A. Narad, "Teacher Effectiveness Among Secondary School Teachers Influence of Principals Leadership Styles," Journal of the Gujarat Research Society, vol. 21, no. (6), pp. 312-321, 2019.

[20] R. Putra, Ernila, D. Komardi, dan Suyono, "Pengaruh Gaya Kepemimpinan, Motivasi, dan Budaya Organisasi Terhadap Kepuasan Kerja dan Kinerja Guru Pada SMKN 4 Pekanbaru," Procuratio: Jurnal Ilmiah Manajemen, vol. 7, no. (4), pp. 470-483, 2019. 